\title{
NSSI (NONSUICIDAL SELF-INJURY) PADA DEWASA MUDA DI JAKARTA: STUDI FENOMENOLOGI INTERPRETATIF
}

\author{
Olphi Disya Arinda \& Winarini Wilman D. Mansoer \\ Fakultas Psikologi, Universitas Indonesia, Jl. Margonda Raya, Pondok Cina, Beji, Depok 16424, Indonesia
}

Korespondensi: disyarinda@gmail.com

\section{NSSI (NONSUICIDAL SELF-INJURY) OF EMERGING ADULTS IN JAKARTA: AN INTERPRETATIVE PHENOMENOLOGICAL APPROACH}

\begin{abstract}
The phenomenon of non-suicidal self-injury (NSSI) is still understudied in Indonesia. In fact, exploring such a phenomenon is essential to guide our understanding of the phenomenon and to develop appropriate clinical treatment. This study aims to explore the experience and meaning-making process of individuals who committed NSSI. Using a phenomenological approach, interviews were conducted to four young adult women (aged 21-22 years) in Jakarta with a history of NSSI. Interpretative phenomenological analysis identified five themes in their experiences: a sense of relief, secrecy, a lack of mindfulness, repetitiveness, and suicidal tendencies. The longer the individual committed NSSI, the more likely they were to commit suicide. All participants interpreted their NSSI experience as a coping strategy to deal with feelings of emptiness and negative emotions. This study provides useful insight for prevention and treatment of NSSI.
\end{abstract}

Manuscript type: Original Research

\section{Article history:}

Received 14 July 2020

Received in revised form 12 August 2020

Accepted 29 September 2020

Available online 19 November 2020

\section{Keywords:}

interpretative phenomenological analysis

NSSI

young adult

\begin{abstract}
Abstrak
Studi di Indonesia tentang perilaku menyakiti diri sendiri dengan motif tidak bunuh diri (non-suicidal selfinjury; NSSI) berdasarkan penghayatan pelaku belum banyak dilakukan. Padahal hal ini penting untuk memperkaya pemahaman akan kemunculan NSSI serta strategi penanganan klinisnya. Penelitian ini bertujuan untuk memahami pengalaman dan pemaknaan individu yang melakukan NSSI. Dengan menggunakan pendekatan fenomenologis, wawancara dilakukan pada empat perempuan dewasa muda (usia 21-22 tahun) di Jakarta yang melakukan NSSI yang dimulai pada usia yang berbeda-beda. Analisis fenomenologis interpretatif mengidentifikasi adanya lima tema dalam pengalaman mereka: perasaan lega, sembunyisembunyi, tanpa kesadaran penuh, berulang, dan kecenderungan bunuh diri. Semakin lama individu melakukan NSSI, maka semakin besar kemungkinannya untuk melakukan bunuh diri. Keempat partisipan memaknai pengalaman NSSI-nya sebagai cara untuk mengatasi perasaan hampa dan emosi-emosi negatif. Penelitian ini memberi informasi yang diharapkan bermanfaat bagi upaya pencegahan dan penanganan kasus NSSI.
\end{abstract}

Kata Kunci: analisis fenomenologis interpretatif, dewasa muda, NSSI

\section{Dampak dan Implikasi dalam Konteks Ulayat}

Hasil studi ini menekankan pada keengganan partisipan untuk menceritakan pengalamannya kepada orang yang dianggapnya dekat terkait perilaku menyakiti diri dengan motif untuk tidak bunuh diri. Lebih lanjut, studi ini memberi indikasi awal mengenai konteks budaya di Indonesia, di mana partisipan memilih untuk berkonsultasi pada praktisi kesehatan mental profesional daripada menceritakan permasalahannya pada keluarga. Temuan ini menyajikan konteks yang paradoksikal, ditunjukkan dengan tabunya isu mengenai kesehatan mental pada masyarakat Indonesia, tetapi di sisi lain mengilustrasikan kesadaran individual yang meningkat terhadap layanan kesehatan mental profesional. 


\section{PENDAHULUAN}

Pada masa dewasa muda, individu dituntut melakukan berbagai tugas perkembangan yang sama sekali berbeda dengan tugas pada tahap perkembangan sebelumnya (masa remaja). Tahap ini merupakan periode perkembangan yang dikarakteristikkan oleh ketidakpastian tentang komitmen interpersonal dalam konteks relasi romantis dan tekanan yang kuat untuk mengemban tanggung jawab sebagai orang dewasa; kondisi tersebut sering hadir dengan kurangnya kesiapan keuangan atau kematangan psikologis untuk melakukannya (Arnett, 2000; Schwartz dkk., 2013). Peralihan dari masa remaja ke masa dewasa kerap menjadi salah satu periode kehidupan yang berpotensi membuat individu mengalami stres (Mahtani dkk., 2017). Individu memerlukan strategi coping terhadap stres, namun tidak semua individu memilih strategi coping yang tepat.

Salah satu wujud dari strategi coping yang tidak adaptif adalah dengan menyakiti diri sendiri tanpa motif untuk bunuh diri (nonsuicidal self-injury; NSSI) (Biromo, 2015; Hawton dkk., 2012). NSSI termasuk ke dalam perilaku self-injurious behavior, yang merujuk secara luas pada setiap perilaku seseorang yang dengan sengaja melukai diri sendiri secara langsung, baik dengan niat bunuh diri atau tanpa ada niat bunuh diri (Nock, 2008). Perilaku NSSI dilakukan tanpa ada niat untuk bunuh diri, meskipun orang yang melakukan tindakan NSSI mungkin saja memiliki ide bunuh diri dan pikiran pasif tentang mati (Favazza, 2012). Manifestasi NSSI dapat berupa memotong, membakar, memukul diri sendiri, membenturkan kepala sendiri, mencabut rambut sendiri, terus-menerus menggaruk dirinya sendiri, mengelupas atau mengganggu penyembuhan luka, dan mematahkan tulang (Brown \& Kimball, 2012). Perilaku NSSI juga dilakukan oleh pasien dengan gangguan jiwa lainnya, seperti depresi dan gangguan bipolar (Biromo, 2015). Meskipun demikian, ada banyak kasus NSSI yang belum dilaporkan dengan diagnosis dari profesional kesehatan mental. Motif munculnya perilaku NSSI adalah untuk mendapatkan perhatian dan bantuan dari orang lain serta untuk melarikan diri dari situasi yang sulit (Rodham dkk., 2004).

NSSI terbagi menjadi dua klasifikasi, yaitu patologis dan non patologis (Favazza, 2012). NSSI yang bersifat non patologis termasuk modifikasi tubuh, seperti tato tubuh atau tindik tubuh. Perilaku modifikasi tubuh dapat dikatakan sebagai sublimasi dari NSSI patologis. Sementara itu, NSSI yang bersifat patologis merupakan salah satu cara dalam meregulasi emosi (Favazza, 2012). Menurut Favazza (2012), NSSI yang bersifat patologis digolongkan ke dalam empat kategori deskriptif, yaitu NSSI mayor, NSSI stereotipik, NSSI kompulsif, dan NSSI impulsif. 
Perilaku NSSI mayor merupakan tindakan yang tidak menetap yang merusak jaringan tubuh sendiri, sebagai akibat dari kondisi psikotik. Sementara itu, perilaku NSSI stereotipik umumnya diasosiasikan dengan kondisi retardasi mental yang parah dan mendalam, dilakukan berulang secara monoton, dengan pola ritmis, dan ditunjukkan tanpa ada perasaan malu atau bersalah di depan umum, seperti memukul dan menampar diri. Perilaku NSSI kompulsif meliputi perilaku berulang, seperti mencakar kulit dan menggigit kuku, menjambak rambut (trichotillomania), serta mencongkel kulit (delusional parasitosis). Perilaku NSSI impulsif terdiri dari berbagai perilaku, seperti menyayat kulit, membakar, dan mengukir kulit; menusukkan benda tajam di bawah kulit atau di dada atau perut; mengelupas bekas luka; dan membenturkan tulang-tulang tangan atau kaki. Perilaku-perilaku ini biasanya terjadi secara episodik dan lebih sering dilakukan oleh perempuan. Perilaku NSSI impulsif menjadi berbahaya ketika perilaku ini dilakukan berulang dan bersifat adiktif. Sebenarnya ada banyak cara yang dilakukan orang dengan NSSI impulsif, namun yang paling banyak dilaporkan adalah menyayat tangan.

\section{Faktor-faktor yang Berkaitan dengan NSSI}

Saat ini, perkembangan penelitian seputar NSSI menunjukkan bahwa kegagalan dalam proses pembentukan identitas, serta konflik pada hubungan sebaya dapat memunculkan NSSI selama periode usia remaja dan dewasa muda (Claes dkk., 2014). Remaja yang kerap menjadi korban kekerasan dari temannya, yang mempersepsikan harga diri serta kompetensi diri yang rendah, serta yang memiliki persepsi negatif tentang teman sebaya berisiko melakukan NSSI di kemudian hari (Victor dkk., 2019). Selain itu, remaja yang orang tuanya kerap memberi hukuman fisik secara kasar, kurang mengawasi, dan memiliki kualitas kedekatan yang rendah akan memiliki risiko yang lebih besar untuk melakukan NSSI jika dibandingkan dengan remaja yang tumbuh melalui pengasuhan yang positif (Victor, dkk., 2019). Oleh karena itu, NSSI banyak dialami oleh remaja dan dewasa muda sebagai bentuk pelarian dari tekanan dan strategi penanggulangan.

Sebagai salah satu strategi penanggulangan stres yang maladaptif, perilaku NSSI dianggap penting untuk diteliti terutama pada konteks klinis. Meskipun demikian, masih belum banyak literatur yang memaparkan perspektif mereka yang berjuang dengan perilaku NSSI (Brown \& Kimball, 2012).

Studi terdahulu mengidentifikasi berbagai faktor yang berkaitan dengan perilaku NSSI, seperti kondisi kesehatan mental subjek, status sosial ekonomi, pengalaman kekerasan, hingga gaya hidup tidak sehat (Mars dkk., 2014). Penelitian Swahn dkk. (2012) menunjukkan bahwa status 
sosial ekonomi rendah, masalah perilaku, gangguan somatik, gangguan makan, masalah pikiran, regulasi emosi yang buruk, komunikasi yang buruk, penganiayaan anak, perilaku berisiko dan agresif, serta penggunaan narkoba dikaitkan dengan ide bunuh diri atau perilaku menyakiti diri sendiri pada remaja.

Terkait gender, terdapat inkonsistensi dalam berbagai riset yang membahas mengenai perbedaan prevalensi perilaku NSSI pada perempuan dan laki-laki. Beberapatidak menemukan perbedaan prevalensi antara perempuan dan laki-laki pada kecenderungan melakukan NSSI (Bresin \& Schoenleber, 2015). Namun, beberapa riset lainnya menemukan bahwa perempuan lebih banyak melaporkan perilaku NSSI daripada laki-laki (Bresin \& Schoenleber, 2015). Meskipun demikian, NSSI pada laki-laki tercatat cenderung tidak lebih parah manifestasi gejala psikopatologinya jika dibandingkan dengan perempuan (Victor dkk., 2018).

Kecenderungan dan prevalensi yang lebih tinggi untuk melakukan NSSI pada perempuan pada kebanyakan studi tidak dielaborasi berdasarkan pengalaman subjektif, namun dibahas secara kolektif. Oleh karena itu, dibutuhkan pembahasan yang lebih mendalam mengenai pemaknaan akan perilaku NSSI pada perempuan sebagai penelitian awal untuk melihat bagaimana dinamika gender, terutama perempuan, berinteraksi terhadap perilaku NSSI.

Peristiwa yang menjadi tekanan dalam hidup juga berperan dalam kemunculan perilaku NSSI. Meskipun belum diketahui secara pasti apakah tekanan hidup menjadi penyebab atau konsekuensi dari munculnya NSSI - atau apakah tekanan hadir secara bersamaan dengan perilaku NSSI -, tekanan hidup menjadi salah satu faktor risiko sekaligus dampak dari perilaku NSSI (Liu dkk., 2016). Adapun peristiwa yang signifikan menjadi tekanan dalam hidup pada umumnya berkaitan dengan relasi dengan anggota keluarga lain, terutama dengan orang tua (Martin dkk., 2016). Disregulasi emosi diketahui secara tidak langsung memengaruhi kecenderungan perilaku NSSI melalui kemunculan gejala dan percobaan bunuh diri (Kranzler dkk., 2016). Sementara itu, pada studi meta analisis terhadap 48 penelitian, ditemukan bahwa semakin besar disregulasi emosi, semakin tinggi pula risiko NSSI pada individu setelah mengontrol berbagai variabel demografis, seperti jenis kelamin dan usia (Wolff dkk., 2019). Hal ini menunjukkan bahwa disregulasi emosi dapat memengaruhi kecenderungan NSSI, baik secara langsung maupun tidak langsung. Dengan demikian, perlu adanya pemahaman mengenai penghayatan individu terhadap mekanisme regulasi emosi yang mengarah pada perilaku NSSI untuk melihat bagaimana peran disregulasi emosi pada kecenderungan untuk melakukan NSSI. 


\section{Kondisi Psikologis Dewasa Muda dan Kaitannya dengan NSSI}

Dewasa muda merupakan periode perkembangan setelah remaja menuju periode perkembangan dewasa. Periode perkembangan dewasa muda merupakan periode perkembangan yang unik dan penting, yang dicirikan dengan perubahan cepat pada aspek kepribadian, sosial, dan akademik (Arnett, 2016). Pada periode perkembangan ini, dewasa muda mengalami berbagai perubahan di banyak aspek yang unik dan penting, sehingga dewasa muda rentan mengalami stres (Arnett, 2016). Dewasa muda yang mengalami tekanan psikologis dan tidak mampu meregulasi emosinya dengan baik dapat mengarah pada perilaku negatif, termasuk self-injury (Kiekens dkk., 2017).

Beberapa penelitian telah dilakukan dalam memahami perilaku NSSI pada dewasa muda. Salah satunya adalah studi Kiekens dkk. (2017) yang menunjukkan bahwa peran kepercayaan pribadi begitu penting terhadap kemampuan mengatur emosi secara efektif dalam menghentikan perilaku NSSI. Penelitian tersebut juga membuktikan bahwa hubungan antara dukungan sosial, kepuasan hidup, dan perilaku NSSI dimediasi oleh kemampuan yang dipersepsikan untuk meregulasi emosi.

Dewasa muda yang melakukan NSSI berpotensi untuk menghadapi tantangan lainnya, termasuk gangguan kejiwaan (Taliaferro \& Muehlenkamp, 2015), pikiran dan perilaku untuk bunuh diri (Hamza \& Willoughby, 2016), dan rendahnya performa akademik (Kiekens dkk., 2017.

\section{Tujuan Studi}

NSSI perlu ditelaah melalui penghayatan mendalam dari individu yang melakukannya, untuk memungkinkan eksplorasi terhadap pengalaman-pengalaman khas dari setiap individu pelaku NSSI. Di Indonesia, peneliti belum menemukan adanya penelitian mengenai NSSI yang khusus dibahas dalam penelitian fenomenologi interpretatif. Beberapa penelitian di Indonesia yang telah dilakukan lebih banyak membahas tentang dinamika terbentuknya perilaku NSSI dan belum mengelompokkan tema-tema khusus terkait penghayatan partisipan pelaku NSSI.

Studi ini bertujuan untuk memahami penghayatan yang dimiliki oleh partisipan pelaku NSSI dan mengeksplorasi alasan mengapa individu dewasa muda mengulangi atau mempertahankan perilaku NSSI, serta persepsi mereka tentang penghentian menyakiti diri sendiri atau pemulihan, dengan menggunakan analisis fenomenologi interpretatif (IPA) dari wawancara mendalam dalam format semi terstruktur. Dengan menjelajahi penghayatan pribadi individu dewasa muda yang melakukan NSSI, peneliti berharap dapat mengidentifikasi strategi yang tepat untuk meningkatkan 
dukungan dalam pemulihan perilaku NSSI, baik bagi praktisi kesehatan mental maupun bagi oleh orang terdekat pelaku.

\section{METODE}

\section{Partisipan}

Teknik pemilihan partisipan adalah purposive sampling untuk menjaga homogenitas kelompok dengan jumlah yang dianggap optimal untuk dianalisis melalui pendekatan IPA (Smith dkk., 2009). Semua partisipan harus pernah melakukan NSSI dalam satu bulan terakhir. Calon partisipan direkrut melalui pengumuman daring di salah satu sosial media komunitas kesehatan mental. Calon partisipan yang merasa sesuai dengan kriteria dan bersedia menjadi calon partisipan langsung menghubungi peneliti pada nomor telepon yang tertera melalui Whatsapp. Peneliti mendapatkan sekitar 20 orang perempuan berusia 20-25 tahun yang mengaku pernah atau sedang melakukan NSSI. Semua calon partisipan diwawancara lebih lanjut oleh peneliti melalui pesan singkat untuk memverifikasi kesesuaian kondisinya dengan kriteria studi. Beberapa di antaranya telah berhenti melakukan NSSI, namun sebagian lagi masih melakukan hingga bulan Januari 2019.

Dari 20 responden yang mendaftar, 12 orang memenuhi kriteria studi dan mengaku hingga saat ini masih melakukan NSSI. Perilaku NSSI yang dilakukan juga beragam, antara lain cutting (menyanyat bagian tubuh dengan benda tajam), starving (sengaja melaparkan diri dengan tidak makan dan/atau minum), membenturkan kepala ke tembok, menggigit kuku, menjambak rambut, dan sebagainya. Beberapa partisipan pernah berkonsultasi ke praktisi kesehatan mental profesional, seperti ke psikolog dan psikiater, sehingga partisipan-partisipan tersebut telah mendapatkan diagnosis akan gangguan mental yang dialaminya (mencakup gangguan bipolar, depresi, dan kepribadian ambang borderline).

Pada partisipan yang masih melakukan NSSI, pemicu munculnya perilaku tersebut diakui beragam. Salah satu yang terbanyak adalah melakukan NSSI akibat kondisi atau situasi yang membuat stres, seperti situasi pertengkaran orang tua di rumah atau kondisi episode depresi yang sedang dialami bagi partisipan dengan gangguan bipolar. Beberapa calon partisipan tidak dapat memberitahukan frekuensi pasti melakukan NSSI karena keterbatasan memori. Dari 12 orang calon partisipan, hanya empat orang yang bersedia untuk diwawancara lebih lanjut. Akhirnya, empat orang partisipan tersebut menghubungi peneliti melalui jalur komunikasi Whatsapp dan 
menyatakan kesediaan untuk menjadi partisipan. Keempat partisipan tersebut adalah perempuan berusia 21-22 tahun dan tinggal di Jakarta.

Tabel 1.

Data Demografis Partisipan

\begin{tabular}{|c|c|c|c|c|c|}
\hline Inisial & Usia & $\begin{array}{l}\text { Kegiatan } \\
\text { saat ini }\end{array}$ & $\begin{array}{l}\text { Usia pertama kali } \\
\text { melakukan NSSI }\end{array}$ & $\begin{array}{c}\text { Perkiraan } \\
\text { frekuensi } \\
\text { melakukan NSSI }\end{array}$ & $\begin{array}{c}\text { Diagnosis dari } \\
\text { psikiater/psikolog }\end{array}$ \\
\hline SY & 21 & Kuliah & 7 tahun & $\begin{array}{c}\text { Hampir setiap } \\
\text { hari }\end{array}$ & BPD \\
\hline $\mathrm{AM}$ & 22 & Bekerja & 14 tahun & 1-2 kali seminggu & - \\
\hline VV & 21 & Kuliah & 20 tahun & 3-4 kali seminggu & Bipolar disorder \\
\hline AN & 21 & $\begin{array}{c}\text { Kuliah dan } \\
\text { bekerja }\end{array}$ & 21 tahun & $\begin{array}{l}\text { Hampir setiap } \\
\text { hari }\end{array}$ & $\begin{array}{c}\text { Major depressive } \\
\text { disorder }\end{array}$ \\
\hline
\end{tabular}

\section{Desain}

Penelitian ini bertujuan untuk mengungkapkan pengalaman individu usia dewasa muda yang melakukan NSSI. Penelitian ini menggunakan metode kualitatif yang tidak hanya berfokus pada pengumpulan, analisis, dan menuliskan data, tetapi juga dapat fleksibel dan mengalir selama proses penelitian (Creswell, 2014). Pendekatan kualitatif yang digunakan adalah fenomenologi interpretatif, khususnya Interpretative Phenomenological Analysis (IPA) yang bertujuan untuk mendapatkan pemahaman yang lebih baik tentang sifat dan kualitas fenomena ketika diungkapkan (Willig, 2013). IPA sebelumnya telah digunakan untuk menelaah NSSI pada orang dewasa dan remaja (Adams dkk., 2005; Hunter dkk., 2013) dan secara umum telah memberikan kontribusi penting untuk memahami pengalaman penyakit dalam kesehatan mental (Smith, 2011). Penelitian kualitatif terhadap fenomena kesehatan yang kompleks (seperti menyakiti diri) menghasilkan data yang kaya dan ilustratif, serta dapat menyoroti faktor-faktor baru yang tidak diteliti dalam penelitian kuantitatif (Wadman dkk., 2017). Sementara itu, belum terdapat penelitian yang menelaah NSSI dengan metode IPA untuk menggali penghayatan pada partisipan dewasa muda di Jakarta.

\section{Prosedur}

Setiap partisipan diwawancarai pada waktu dan tempat yang berbeda dengan wawancara semi terstruktur oleh peneliti. Dari empat partisipan, dua orang di antaranya diwawancarai secara langsung, sementara dua orang partisipan lainnya diwawancarai melalui telepon. Peneliti terlebih dahulu menanyakan tentang data-data pribadi, seperti nama (inisial), usia, kota domisili, dan kesibukan saat ini (apakah sedang kuliah, bekerja, dan sebagainya). Peneliti juga menanyakan data 
terkait pengalaman NSSI, seperti apakah masih melakukan NSSI, sejak kapan melakukannya, bentuk-bentuk NSSI, frekuensi melakukan NSSI, dan apakah mengalami kondisi mental tertentu. Informasi pribadi dan data terkait NSSI ditanyakan oleh peneliti melalui obrolan pada platform WhatsApp. Setelah partisipan setuju untuk diwawancarai, peneliti memberikan informed consent untuk dibaca secara langsung dan dipahami partisipan, memberikan kesempatan pada partisipan apabila ada pertanyaan yang membingungkan, lalu meminta partisipan untuk menandatangani lembar kesetujuan. Untuk partisipan yang tidak ditemui secara langsung, informed consent diberikan melalui surat elektronik dan menyatakan persetujuan melalui telepon, kemudian menyertakan tanda tangan pada lembar informed consent yang dikirimkan kembali secara elektronik kepada peneliti.

Sebelum wawancara dimulai, peneliti mempersiapkan pedoman wawancara yang telah diujicobakan terlebih dahulu kepada dua orang informan yang sesuai dengan karakteristik partisipan. Dari hasil uji coba, tidak terlalu banyak dilakukan perbaikan. Namun, terdapat beberapa perubahan terhadap pertanyaan, seperti mengubah pertanyaan tertutup menjadi terbuka, mengubah sistematika alur pertanyaan, dan perubahan dalam penggunaan istilah agar lebih dapat dimengerti oleh partisipan.

Wawancara didahului dengan membangun kualitas relasi interpersonal antara peneliti dan partisipan. Peneliti juga menjelaskan latar belakang dan tujuan penelitian terlebih dahulu. Partisipan yang bertemu secara langsung dengan peneliti hadir sendiri tanpa ditemani oleh orang lain dan ditemui di sebuah kafe yang berlokasi dekat dengan kediaman partisipan sesuai dengan permintaan partisipan.

Wawancara dilakukan melalui pertanyaan terbuka, kemudian dilanjutkan dengan pertanyaan lanjutan. Pertanyaan dalam wawancara termasuk pertanyaan spesifik terkait apa yang menjadi pemicu untuk melakukan NSSI (contoh: 'NSSI yang kamu lakukan pertama kali itu pemicunya itu apa?', 'Adakah pemicunya sebelum kamu melakukan itu?'). Informasi mengenai latar belakang usia dan diagnosis kesehatan mental partisipan tertulis di Tabel 1. Partisipan juga ditanyakan tentang metode atau bentuk-bentuk NSSI, pada usia berapa pertama kali melakukan NSSI, dan seberapa sering melakukan NSSI. Terkait saturasi data wawancara, peneliti menemukan adanya pola yang berulang beberapa kali dari jawaban partisipan, sehingga tidak ditemukan informasi yang baru.

Wawancara direkam dan dibuat dalam transkrip verbatim. Rata-rata rekaman wawancara berlangsung 45 menit hingga satu jam. Peneliti juga telah melakukan verifikasi ketepatan data dan mengklarifikasi data jika ada yang kurang tepat ditulis oleh peneliti kepada setiap partisipan. 
Penelitian telah mendapat persetujuan dari Komisi Kaji Etik Fakultas Psikologi Universitas Indonesia (Nomor: 556/F.Psi/Komite Etik/PDP.04.00/2019).

\section{Teknik Analisis}

Transkrip wawancara dianalisis menggunakan IPA sesuai dengan pedoman yang diterbitkan (Smith dkk., 2009). Pada penelitian ini, peneliti terlebih dahulu membaca seluruh transkrip verbatim. Dari beberapa jawaban partisipan, peneliti mengelompokkan tema-tema. Peneliti pertama memberikan kode pada transkrip yang kemudian ditunjau ulang oleh peneliti kedua. Dari pemberian kode tersebut, peneliti pertama dan kedua secara bersama-sama mengelompokkan sebagai tematema. Analisis tema dilakukan oleh peneliti pertama dengan masukan dari peneliti kedua.

Analisis data dilakukan dengan melihat adanya siklus yang berulang dan dilihat secara induktif seperti yang dijelaskan oleh Smith dkk. (2009). Sesuai dengan pedoman IPA, peneliti memulai dengan membaca kembali setiap transkrip sebagai individu dan entitas idiografis sambil mencari tema dalam setiap pernyataan partisipan. Peneliti memperhatikan penggunaan metafora, frasa atau makna yang diulang oleh setiap partisipan, juga melihat proses partisipan dalam menjelaskan (termasuk jeda, gagap, atau ketika mengalami kesulitan menyatakan hal-hal tertentu), serta informasi tentang nilai-nilai, hubungan, dan gagasan yang secara eksplisit dinyatakan partisipan sangat penting bagi mereka, untuk sampai pada analisis tematik dalam cerita masingmasing individu. Setelah penulis memeriksa transkrip masing-masing partisipan dengan melihat saturasi data, mencatat apa yang tampaknya menjadi pesan inti, serta mengidentifikasi tema yang paling sentral bagi pemahaman individu tentang pengalaman mereka, maka tema-tema yang muncul dari setiap wawancara kemudian diangkat untuk dicocokkan satu sama lain. Melalui prosedur ini, peneliti dapat melihat adanya lima tema yang menjadi inti dari pernyataan setiap partisipan terkait penghayatannya.

\section{ANALISIS DAN HASIL}

Berdasarkan hasil wawancara pertama maupun wawancara kedua pada seluruh partisipan, gagasan untuk melakukan NSSI cukup beragam. Hal ini dipengaruhi oleh perbedaan latar belakang kehidupan keluarga dan pengalaman di masa lalu. Relasi dengan orang tua dan kondisi kesehatan mental partisipan juga menjadi pengaruh munculnya gagasan untuk melakukan NSSI. 


\section{Latar Belakang Partisipan}

$S Y$

SY merupakan seorang perempuan yang mengaku telah mendapatkan diagnosis borderline personality disorder, depresi mayor, dan post-traumatic stress disorder oleh psikiater sejak SMA. Saat ini, SY tengah menjalani cuti kuliah sehingga aktivitasnya tidak sesibuk biasanya. SY tinggal dengan ibu kandungnya dan seorang adik laki-laki yang terpaut usia enam tahun dengannya. Ibu dan ayahnya telah bercerai sejak adiknya baru lahir, sehingga membuatnya jarang bertemu dengan ayahnya sejak saat itu. Menurut SY, ayahnya tetap memberikan nafkah secara finansial hingga saat ini, meskipun ia hampir tidak pernah menghabiskan waktu bersama dengan ayahnya.

Awal mula SY melakukan NSSI adalah ketika ia berusia 7 tahun. Saat itu, ia melakukan NSSI dengan membenturkan kepala dan melukai tangan dengan penggaris. SY menyatakan bahwa hal tersebut dilakukan karena adanya masalah keluarga dan dengan teman-teman. SY juga menceritakan bahwa adiknya pernah melakukan sesuatu terhadapnya yang sangat membekas di ingatannya. Namun, SY enggan menceritakan secara detail perilaku tersebut. Sejak saat itu, SY merasakan trauma yang cukup mendalam hingga saat ini. Menurut SY, hubungannya dengan sang adik tidak begitu baik. Begitu pula hubungan dengan ibunya karena menurut SY ibunya kerap menyepelekan masalah yang tengah dihadapinya dan kurang memperhatikan kondisi kesehatan mentalnya.

$A N$

AN merupakan seorang perempuan yang saat ini sedang menempuh pendidikan perguruan tinggi. AN mengaku bahwa pertama kali melakukan NSSI ketika lulus SMP dan akan mendaftar SMA. Saat itu, AN kecewa dengan dirinya sendiri karena tidak lolos pendaftaran di SMA tujuannya karena nilai ujian yang menurutnya jelek. Kekecewaan tersebut semakin mendalam ketika AN merasa bahwa teman-temannya yang menyontek justru dapat lolos pendaftaran SMA tersebut. Perasaan kecewa ini yang membuatnya secara tidak sadar melakukan NSSI untuk pertama kalinya dengan cara mencengkram erat tangannya sendiri hingga terasa sangat sakit.

Sejak pertama melakukan NSSI, AN mengaku tidak lagi melakukannya hingga usianya menginjak 17 tahun yang mana pada saat itu AN juga sedang menghadapi masalah di dalam keluarganya. AN merasa orang tuanya tidak begitu peduli dan tidak mendengarkan apa yang dirasakannya, serta cenderung menasihati dengan cara menyalahkan perilaku AN. Dengan kata lain, salah satu hal yang memicu perilaku NSSI dalam kasus AN adalah hubungan dengan keluarga yang 
kurang harmonis. AN merasa membutuhkan sosok orang tua yang mendukung dan memahami, namun orang tuanya justru menunjukkan sikap yang cenderung mengabaikannya.

$V V$

VV merupakan seorang perempuan yang saat ini baru lulus pendidikan tinggi dan sedang menjalankan bisnisnya. Menurut VV, orang tuanya sangat peduli dengan dirinya. Namun di sisi lain, VV merasa bahwa orang tuanya mengawasi dan mengontrolnya secara berlebihan, sehingga membuatnya tidak begitu nyaman. Selain itu, VV juga merasa orang tuanya sangat sensitif mengenai kondisinya yang pernah didiagnosis gangguan bipolar. Orang tua VV menjadi sering menangis dan bersedih. Hal ini pula yang membuat VV cenderung menutup diri dari orang tuanya karena merasa tidak nyaman.

Ketika diminta untuk menjelaskan apa yang menjadi pemicunya melakukan NSSI, VV merasa bingung karena menurutnya berbagai aspek di kehidupannya berjalan dengan cukup baik. Menurut VV, pencetus utama dirinya melakukan NSSI ialah karena ada perasaan hampa. Tidak ada emosi yang dapat dirasakannya, baik senang maupun sedih, sehingga VV memerlukan cara lain untuk dapat merasakan emosi. VV juga sering merasakan ada banyak suara di dalam kepalanya yang sangat berisik ketika ia sedang berdiam atau ketika akan tidur. Hal ini juga kadang mendorongnya untuk melakukan NSSI.

\section{$A M$}

AM merupakan seorang perempuan yang saat ini bekerja dan tinggal bersama dengan ibunya. Sejak orang tuanya bercerai satu tahun yang lalu, AM menjadi tulang punggung keluarga. Masalah-masalah yang terjadi dalam keluarga selama proses perceraian orang tuanya turut menjadi pemicu perilaku NSSI yang dilakukannya. AM merasa bahwa ia telah melakukan yang terbaik untuk menafkahi keluarganya, namun ibunya sering berkata kasar kepadanya dan menyalahkannya. Hal tersebut membuat AM merasa tidak berguna dan cenderung merasa diabaikan.

Secara umum, AM menggambarkan kondisi dirinya sebagai anak perempuan yang sering disalahkan oleh ibunya. Apa yang dirasakannya terhadap situasi tersebut tidak dapat dikomunikasikan dengan baik pada ibunya. Ketika AM mencoba untuk membicarakannya, ibunya tetap menyalahkan dan merasa AM tidak perlu mengeluhkan hal tersebut. AM kemudian merasa tidak dapat melampiaskan emosinya, sehingga memilih melakukan NSSI sebagai bentuk ekspresi perasaannya setiap ada masalah dengan ibunya. 


\section{Ringkasan Latar Belakang Partisipan}

Usia onset pertama kali melakukan NSSI beragam. Ada partisipan yang pertama kali melakukan NSSI pada usia 7 tahun, 14 tahun, dan ada pula yang melakukannya pertama kali pada usia 20 tahun. Metode atau cara dalam melakukan NSSI juga beragam. Keempat partisipan mengaku pernah melakukan cutting, yaitu melukai bagian tubuh dengan cara menyayat atau membuat luka terbuka. Bentuk NSSI lainnya yang juga dilakukan oleh beberapa partisipan adalah memukul diri sendiri, membenturkan kepala ke benda keras, dan meninju tembok atau benda keras hingga memar. Partisipan melaporkan bahwa tidak ada frekuensi teratur dalam melakukan NSSI. Saat-saat dalam melakukan NSSI sangat beragam dan tidak berada dalam rentang waktu tertentu. Namun, dapat disimpulkan dari hasil wawancara bahwa keempat partisipan melaporkan NSSI dilakukan setidaknya satu bulan sekali. Beberapa partisipan menyatakan bahwa NSSI dapat dilakukan pada saat pemicu hadir dan hal tersebut datang secara tidak menentu.

\section{Tema-Tema Utama}

Tema-tema diidentifikasi pada partisipan dalam rangka memahami apa yang melatarbelakangi partisipan melakukan NSSI dan apa yang dirasakannya pada saat melakukan NSSI. Kutipan verbatim dari transkrip wawancara digunakan untuk mengilustrasikan tema-tema. Berikut adalah tema-tema yang tergambarkan dalam wawancara dengan keempat partisipan, yaitu: 1). perasaan lega; 2). sembunyi-sembunyi; 3). tanpa kesadaran penuh; 4). berulang; dan 5). pikiran atau tindakan untuk mengakhiri hidup.

\section{NSSI Membuat Perasaan Menjadi Lebih Lega}

Semua partisipan mengaku merasa lebih baik setelah melakukan NSSI. Secara khusus, keempat partisipan menyampaikan bahwa melakukan NSSI membuat perasaan lebih lega atau terlepas dari emosi atau pikiran negatif.

[Merasa] puas, lega ... ya lepas sih emosinya. (SY)

Kayak apa ya.. Kayak lagi marah-marah trus akunya NSSI tuh kayak lega aja sih udahnya.. Gak ngerasa sakit, pas udahannya mungkin kayak oh iya ya lebam oh iya ya lecet.. Tapi pas awal-awal sih kayak lega, lega. Karena aku rasa nangis doang tuh gak cukup gitu. (AM) 
Kayak jadi lega aja gitu lho. Karena biasanya kalau ngelakuin itu kan jadi benar-benar ntah kesel atau kecewa. Jadi lega aja, jadi kayak ada yang dilampiasin. (AN)

Merasa better aja sih.. Lebih lega.. Soalnya merasa kayak kosong aja gitu.. Ada feel alive. (VV)

\section{NSSI Dilakukan Tanpa Sepengetahuan Orang Lain atau Sembunyi-Sembunyi}

Keempat partisipan mengungkapkan bahwa NSSI dilakukan secara diam-diam tanpa sepengetahuan orang terdekat, terutama keluarga. Partisipan melakukan NSSI umumnya saat sedang sendiri di dalam kamar pribadi. Beberapa mengungkapkan bahwa mereka juga melakukan NSSI di tempat umum. Namun, ketika dorongan untuk NSSI muncul, mereka segera mencari tempat yang aman dan nyaman untuk melakukannya, seperti di toilet umum.

[Melakukan NSSI] di kamar... atau di kamar mandi kalau lagi di kerumunan. Maksudnya kalau bukan lagi di rumah. (SY)

Jadi bener-bener langsung pas saat itu.. Kebetulan kan lagi di kamar juga, sendiri. Jadi gak ada yang tau juga. (AN)

Kan aku di kamar sendirian, maksudnya aku gak ada yang taulah.. Soalnya aku kayak gitu malem-malem juga sih. (VV)

...jadi kayak ah ya udah... kayak aku langsung lari ke kamar mandi, aku langsung diem, aku langsung mukul diri sendiri, langsung mukul tembok. (AM)

\section{NSSI Dilakukan Tanpa Kesadaran Penuh}

Saat melakukan NSSI, partisipan mengaku bahwa perilaku tersebut sering terjadi tanpa adanya kesadaran penuh. Ketika emosi negatif dirasakan memuncak dan tidak tertahankan, partisipan langsung melakukan NSSI ketika ada kesempatan. Partisipan baru menyadari sesaat setelah melakukan dengan melihat kondisi fisik (seperti berdarah-darah) atau beberapa waktu setelahnya. 
Tergantung ya.. Kalau emang kadang, lebih ke gak sadar sama sekali sih.. Kayak pas udahnya [melakukan NSSI] kayak ah ya udahlah. (AM)

Kalau yang biasanya sih kayak nonjok-nonjok benda keras kayak tembok gitu. Trus sama nyakar-nyakar sampe merasa agak hilang gitu... ternyata tuh sekenceng itu sampai aku tuh nggak nyadar gitu lho kak. Kayak ngecengkram tangan sendiri kayak sampe... ternyata sampe dalem. (AN)

Pokoknya semuanya kayak tiba-tiba aja.. Tiba-tiba udah nyilet-nyilet gitu.. Ga tau sih, pas kejadian aku gak terlalu sadar gitu.. Kayak tiba-tiba selesai yaudah gitu aja. (VV)

Kadang gak sadarnya ya itu yang kayak tiba-tiba aku udah ngelakuin. Tapi aku kayak sadar pas darah udah banyak. (SY)

\section{Keyakinan untuk Mengulang Melakukan NSSI di Kemudian Hari}

Ketika ditanya tentang apakah partisipan memiliki niat untuk berhenti secara tersirat, partisipan mengaku bahwa ada kemungkinan untuk mengulangi perilaku NSSI. Berdasarkan apa yang disampaikan partisipan, terlihat bahwa partisipan meyakini bahwa NSSI sewaktu-waktu dapat dilakukan kembali apabila pemicu atau peristiwa negatif dalam hidup muncul. Terlebih lagi, beberapa partisipan sudah memprediksi kapan NSSI akan dilakukan kembali.

Tapi yaudah, gak ngaruh apa-apa juga mau dibilang jangan kek apa kek, ujung-ujungnya kalau lagi ngerasain hal yang serupa, bakalan kayak gitu lagi. (AN)

Kalo lagi di bawah [merasa tertekan], oh paling seminggu kayak gini, ntar balik lagi [melakukan NSSI]. (VV)

Susah ya karena kalo orang-orang ngomong berhenti tuh ya kayak ngomong gampang, tapi balik lagi ke akunya sendiri emang mau orang bilang aku berhenti tetep balik lagi gitu. (AM) 
Mau gimana lagi [berhenti NSSI], kayak aku mikir mau gimana lagi... kayak pengen berhenti ada pengen.. cuman, gak tau mau ngapain juga. (SY)

\section{Pikiran atau Tindakan untuk Mengakhiri Hidup}

Setiap partisipan mengaku pernah memiliki pikiran untuk mengakhiri hidup ketika ditanya apakah pernah terpikir untuk bunuh diri. Beberapa partisipan menyatakan dengan tegas bahwa tidak pernah memiliki pikiran maupun rencana untuk mengakhiri hidup secara sengaja, tetapi pernah memiliki pikiran untuk menghadapi kematian walaupun caranya bukan dengan bunuh diri. Namun, ada pula partisipan yang sudah pada tahap percobaan bunuh diri.

Pernah ada [pikiran bunuh diri]... Bukan, bukan bunuh dirinya sih, aku kayak pengen mati aja, capek.. Aku gak pengen bunuh diri, pengen mati aja. (VV)

Pernah [ada pikiran bunuh diri]... Tapi gak mencoba sih.. Tapi berpikir terus jadi kayak ngebayangin. Ngebayangin mati gitu... Kalau pengen bunuh diri sih gak. Cuman pengen mati ya iya.. Cuman gak bunuh diri juga, mati kenapa kek. (AN)

Mikir [untuk bunuh diri] iya, nyoba gak...Aku ada di satu waktu yang ngerasa NSSI aja tuh gak cukup, sangat-sangat merasa useless aku ngerasa unwanted one banget kayak gak diinginkan... jadi kayak mau ini aja deh, mau mati aja deh aku ke kamar mandi gak keluarkeluar biarin deh. (AM)

Kalau aku, sampe percobaan [bunuh diri] sih... overdosis obat... Iyaa.. Kayak kenapa gak berhasil, kayak ada ngerasa kenapa aku gak minum lebih banyak, kenapa aku gak ini kenapa gak itu, kenapa gak pake cara yang lebih mematikan. (SY)

\section{DISKUSI}

Berdasarkan apa yang disampaikan partisipan, peneliti menemukan masalah dalam keluarga merupakan hal yang paling berperan dalam mendorong partisipan melakukan NSSI. Masalah keluarga paling spesifik dalam memengaruhi partisipan melakukan NSSI terkait dengan sikap dan perilaku yang ditunjukkan orang tua kepada masing-masing partisipan.

Hal tersebut disampaikan oleh SY yang memiliki orang tua bercerai sejak ia sekolah di bangku SD dan orang tuanya yang dianggap tidak menunjukkan kepedulian terhadap dirinya. Serupa dengan SY, AM juga memiliki orang tua yang bercerai sejak lama dan hidup dengan orang tua tunggal membuat AM merasa bahwa orang tuanya bersikap tidak suportif mengenai kondisi 
mentalnya. Sementara itu, AN merasa orang tuanya cenderung sering bertengkar dan dianggap tidak menunjukkan sikap pengertian yang membuat AN memilih melakukan NSSI untuk melampiaskan emosi negatif yang dirasakannya. Berbeda dari ketiga partisipan lainnya, VV mengaku bahwa orang tuanya justru menunjukkan sikap peduli yang berlebihan, sehingga membuat VV merasa tidak nyaman dengan sikap orang tua tersebut.

Kondisi relasi dengan keluarga yang berkaitan dengan perilaki NSSI juga dibahas dalam beberapa penelitian terdahulu. Latar belakang keluarga dan lingkungan berpengaruh dalam pembentukan kepribadian tertutup, rendah diri, pola pikir yang kaku, dan sulit mengkomunikasikan perasaan, yang kemudian membuatnya rentan terhadap perilaku melukai diri sendiri (Maidah, 2013). Selain itu, perilaku orang tua juga berperan penting dalam memengaruhi keputusan seseorang untuk melakukan NSSI, di mana kurangnya perhatian dan afeksi dari orang tua dapat mendorong seseorang untuk melukai dirinya sendiri yang sering terjadi di luar kendalinya (Kurniawaty, 2012).

Diskusi lebih spesifik terhadap hasil studi diorganisasikan berdasarkan tema-tema utama yang muncul dalam studi ini.

\section{NSSI Membuat Perasaan Menjadi Lebih Lega}

Terdapat kesesuaian antara beberapa penelitian terdahulu dengan penelitian ini, yaitu mengenai kecenderungan partisipan untuk memiliki ide bunuh diri. Nyatanya, NSSI merupakan salah satu prediktor dari perilaku bunuh diri (Rodav dkk., 2014). Pada penelitian ini ditemukan bahwa semua partisipan memiliki keinginan untuk mengakhiri hidup. Meskipun NSSI bukanlah perilaku untuk mengakhiri hidup secara langsung, namun penghayatan yang dimiliki partisipan menunjukkan adanya tekanan yang mendorong partisipan untuk memiliki keinginan mengakhiri hidup. Oleh karena itu, perilaku NSSI perlu diwaspadai sebagai bentuk awal percobaan bunuh diri. Kemudian, regulasi afek seringkali menjadi alasan di balik perilaku NSSI (Wadman dkk., 2017). Beberapa penelitian yang mengandalkan skala sikap maupun studi laboratorium menunjukkan bukti bahwa afek negatif dapat menyebabkan NSSI dan merasa lega setelah mengalami NSSI (Klonsky, 2007). NSSI sebagai bentuk pelepasan emosi sebelumnya juga muncul pada analisis fenomenologis kualitatif dengan partisipan dewasa berusia 19-39 tahun (Brown \& Kimball, 2013).

Tidak dapat dipungkiri bahwa peristiwa negatif dalam hidup (seperti kekerasan dalam keluarga) diasosiasikan dengan NSSI (Hawton dkk., 2012) dan tekanan psikososial dapat memprediksi adanya pengulangan perilaku NSSI lebih dari enam bulan (O'Connor dkk., 2009). 
Maka dari itu, penting untuk mengenali makna di balik perilaku NSSI sebagai salah satu cara dalam menghadapi emosi negatif (Wadman dkk., 2017). Hal ini juga sesuai dengan kerangka teoretis mengenai NSSI sebagai model penghindaran (the experiential avoidance model) (Chapman dkk., 2006).

\section{NSSI Dilakukan Tanpa Sepengetahuan Orang Lain atau Sembunyi-sembunyi}

Meskipun partisipan menutupi perilaku NSSI dari keluarga, semua partisipan tetap mencari bantuan profesional atas dorongan diri sendiri. Dengan kata lain, partisipan lebih nyaman untuk bercerita dan mencari bantuan profesional daripada mencari dukungan keluarga. Hal ini berbeda dengan penelitian sebelumnya yang mengungkapkan bahwa pelayanan kesehatan mental dan intervensi psikologis merupakan ancaman privasi, sehingga dapat menjadi penghalang dalam mengakses dukungan (Cooper dkk., 2011). Saat pertama kali melakukan NSSI, semua partisipan mengaku bahwa perilaku tersebut ditutupi dan tidak diceritakan kepada siapapun. Namun, beberapa partisipan juga menceritakan bahwa ada anggota keluarga yang mengetahuinya setelah beberapa lama melakukan NSSI. Meskipun demikian, hal tersebut tidak menjadi motivasi bagi partisipan untuk berhenti melakukan NSSI. Penelitian ini menunjukkan bahwa pencarian bantuan profesional sangat penting dalam membantu pemulihan individu dengan NSSI, namun peran dan dukungan keluarga juga penting untuk mengoptimalkan pemulihan dan pemeliharaan kesehatan mental. Meskipun isu mengenai kesehatan mental masih dianggap tabu dan lekat dengan stigma, keyakinan akan mendapatkan bantuan yang tepat dan jaminan kerahasiaan dapat menjadi faktor penting dalam mengakses layanan kesehatan mental, seperti yang ditunjukkan partisipan dalam studi ini.

\section{NSSI Dilakukan Tanpa Kesadaran Penuh}

Semua partisipan mengaku bahwa perilaku menyakiti diri sendiri dilakukan tanpa kesadaran penuh. Perilaku ini seolah menjadi cara yang otomatis dilakukan ketika partisipan merasakan adanya tekanan dan masalah emosional. Hal ini sejalan dengan beberapa penelitian sebelumnya yang menyebutkan bahwa NSSI mungkin saja dilakukan secara tidak sadar. NSSI merupakan suatu bentuk perusakan diri yang muncul akibat adanya dorongan untuk melakukan hukuman pada diri sendiri, yang mana dapat terjadi secara tak sadar dan memiliki risiko terhadap keberlangsungan hidup seseorang (Vieira dkk., 2016). Berbeda dengan definisi dari World Health Organization, UK National Institute for Clinical Excellence mendefinisikan NSSI sebagai 'self-poisoning' atau menyakiti diri sendiri, terlepas dari tujuan nyata dari tindakan tersebut (NICE, 2011). Berdasarkan 
definisi tersebut, NSSI dapat terjadi tanpa harus disengaja. Adapun perbedaan definisi tersebut kemungkinan besar dilakukan untuk mengakomodasi bentuk-bentuk NSSI yang berasal dari motif atau impuls yang tidak disadari atau diperkirakan (Pickard, 2015).

\section{Keyakinan untuk Mengulang Melakukan NSSI di Kemudian Hari}

Pada penelitian ini, semua partisipan meyakini akan dilakukannya NSSI di kemudian hari. Meskipun beberapa partisipan sempat berhenti pada beberapa waktu, mereka tetap merasa sulit untuk mencegah diri untuk tidak melakukan NSSI. Keyakinan untuk mengulang kembali melakukan NSSI di kemudian hari selain dapat menghambat pencarian bantuan juga bertentangan dengan layanan klinis yang berfokus menurunkan intensitas perilaku NSSI. Sebuah studi kualitatif mengenai persepsi intervensi untuk menyakiti diri sendiri pada orang dewasa menemukan bahwa regulasi NSSI mungkin tidak selalu melibatkan pencegahan (Hume \& Platt, 2007). Dalam penilaian klinis, profesional perlu mempertimbangkan apakah seseorang ingin atau percaya mereka dapat berhenti melakukannya, yang akan dikaitkan dengan pemahaman subjektif mereka tentang fungsi dari perilaku NSSI tersebut (Shaw, 2006). Menariknya, ketika partisipan ditanya tentang frekuensi menyakiti diri, tanggapan mereka menunjukkan bahwa mereka sempat berhenti dan tidak menyakiti diri selama beberapa minggu atau beberapa bulan, meskipun pada akhirnya kembali melakukan.

\section{Pikiran atau Tindakan Untuk Mengakhiri Hidup}

Meskipun NSSI tidak lantas dilakukan dengan tujuan untuk mengakhiri hidup, semua partisipan mengaku memiliki ide bunuh diri dan di antaranya pernah melakukan percobaan bunuh diri. Ide bunuh diri tersebut muncul tidak selalu bersamaan dengan dorongan untuk menyakiti diri. Hal ini sesuai dengan beberapa penemuan sebelumnya yang menyatakan adanya keterkaitan antara NSSI dan risiko bunuh diri. NSSI umumnya digunakan sebagai salah satu strategi penanggulangan untuk mengatasi tekanan, bukan untuk mengakhiri hidup (Whitlock dkk., 2015). Namun, karena NSSI dan bunuh diri mengindikasikan adanya tekanan dalam hidup, maka penting untuk melihat apakah perilaku menyakiti diri sendiri pada dewasa muda juga termasuk upaya bunuh diri. Hal ini berkaitan dengan ciri-ciri individu yang melakukan upaya bunuh diri, salah satunya adalah berbicara tentang keinginan untuk mengakhiri hidup (Whitlock dkk., 2015). Di sisi lain, NSSI juga dapat menjadi faktor risiko terjadinya bunuh diri (Sinclair \& Leach, 2017). 


\section{Kekuatan dan Keterbatasan Penelitian}

Penelitian ini mengeksplorasi pemaknaan individu dan pengalamannya dengan NSSI pada suatu kelompok dewasa muda yang dalam waktu satu bulan terakhir masih melakukan NSSI. Penelitian kualitatif dengan menggunakan IPA memberikan peluang untuk dapat mengeksplorasi isu yang sulit dan sensitif, tanpa terbatas oleh hipotesis (Smith, 2015). Keunggulan dalam menggunakan IPA berasal dari penyajian deskripsi yang kaya tentang pengalaman suatu kelompok tentang fenomena tertentu dan bagaimana partisipan memahami pengalaman mereka tentang fenomena tersebut. Selain itu, IPA adalah proses interpretatif dan subjektif. Hal ini memungkinkan peneliti untuk mengkonstruksikan secara berbeda-beda mengenai motif partisipan melakukan NSSI yang memiliki potensi untuk memengaruhi analisis (Wadman dkk., 2017).

Tema-tema yang muncul pada penelitian ini menjadi khas hanya pada perempuan usia dewasa awal yang tinggal di kota besar. Penelitian dengan sampel laki-laki atau individu yang tinggal bukan di kota besar memungkinkan adanya tema yang berbeda. Hal ini merujuk pada salah satu tema dalam penelitian ini, di mana partisipan dapat mengakses layanan profesional kesehatan mental di kota tempat mereka tinggal. Tema tersebut mungkin saja tidak muncul atau berbeda jika diteliti pada individu yang tinggal di daerah dengan akses layanan kesehatan mental yang terbatas. Selain itu, durasi wawancara yang relatif singkat dan beberapa wawancara tidak dilakukan dengan tatap muka menghadirkan keterbatasan dalam melakukan observasi dan validasi cerita partisipan, sehingga tidak diketahui apakah partisipan menceritakan pengalamannya secara jujur atau ingin mendapatkan keuntungan lain dari proses ini.

\section{SIMPULAN DAN SARAN}

\section{Simpulan}

Sejalan dengan literatur dan model saat ini, partisipan pada studi ini merasa bahwa NSSI dapat memberikan kenyamanan atau perasaan lega dari tekanan emosional. Meskipun semua partisipan telah mencari bantuan profesional kesehatan mental, namun mereka tetap melakukan NSSI hingga setidaknya dalam satu bulan terakhir saat diwawancarai. Sementara itu, semua partisipan memilih untuk tidak menceritakan perilaku NSSI kepada orang terdekat seperti keluarga. Partisipan juga mengaku tidak pernah memiliki rencana khusus untuk melakukan NSSI, sehingga perilaku tersebut terjadi secara tidak disengaja dan tidak dengan kesadaran penuh. Di sisi lain, partisipan memahami bahwa di kemudian hari, mereka akan tetap melakukan NSSI. Akibatnya, 
hingga saat wawancara berlangsung, partisipan mengaku sulit untuk berhenti karena pada akhirnya mereka akan mengulanginya kembali. Semua partisipan juga mengakui adanya pikiran untuk mengakhiri hidup, meskipun tidak serta merta melakukan upaya bunuh diri.

\section{Saran Teoretis}

Diperlukan adanya pengembangan penelitian lebih lanjut dengan menggabungkan metode penelitian kualitatif dan kuantitatif dalam pengumpulan data terkait NSSI, sehingga hasil penelitian menjadi lebih kaya dan semakin detail dalam memahami pemaknaan perilaku NSSI. Selain itu, dapat pula menggabungkan metode penelitian eksperimental dengan memberikan intervensi psikologis kepada partisipan dengan NSSI.

Dapat diukur pula pada studi lebih lanjut mengenai variabel lain yang spesifik terkait kondisi kesehatan mental, seperti gangguan depresi maupun pola asuh pada remaja agar dapat memperoleh gambaran psikologis partisipan secara mendalam. Selain itu, penelitian selanjutnya dapat membandingkan partisipan dengan latar belakang budaya, mengingat Indonesia memiliki beragam suku yang mungkin dapat memengaruhi cara individu dalam menanggulangi stres. Dengan kata lain, partisipan penelitian juga dapat ditambah untuk mendapatkan gambaran fenomena yang lebih menyeluruh terkait pemaknaan perilaku NSSI, dengan merekrut partisipan pada berbagai kelompok usia, jenis kelamin, maupun latar belakang budaya. Penelitian kualitatif juga disarankan dapat menelaah periode jeda dalam NSSI, sehingga dapat memberikan lebih banyak penjelasan tentang apa yang menghentikan NSSI, terutama dalam konteks pemulihan yang lebih luas.

\section{Saran Praktis}

Pemahaman akan pemaknaan subjektif individu yang melakukan NSSI sangat diperlukan untuk membantu pemulihan, terutama bagi para praktisi kesehatan mental. Meskipun NSSI merugikan diri sendiri, umumnya individu dewasa muda tidak memahami dengan baik apa saja intervensi atau dukungan yang dapat membantu (Townsend, 2015). Dengan demikian, ada kesempatan untuk memanfaatkan keahlian dalam psikologi kesehatan untuk mengembangkan dukungan yang dapat diakses dalam komunitas, termasuk universitas atau perguruan tinggi maupun secara daring yang mempromosikan informasi berbasis bukti tentang strategi dalam mencegah perilaku NSSI, serta mengatasi stigma yang terkait dengan melukai diri sendiri. Kerahasiaan harus ditekankan dalam mengakses dukungan dan informasi tersebut. 
Banyak individu dewasa muda telah melukai diri sendiri selama beberapa tahun dan selama waktu ini, menyakiti diri sendiri telah menjadi rutin dan sering kali lebih parah (Wadman dkk., 2017). Kerusakan diri jangka panjang dapat menyebabkan ketergantungan yang dirasakan, berpotensi meningkatkan risiko, dan menciptakan keyakinan bahwa seseorang tidak dapat bertahan tanpa melakukan NSSI (Wadman dkk., 2017). Layanan klinis perlu berfokus untuk mengatasi dan mengurangi tekanan emosional yang memicu perilaku NSSI daripada menyasar perilaku NSSI tersebut, meskipun tantangannya adalah individu dewasa muda tidak percaya bahwa mereka dapat menghentikan menyakiti diri sendiri sepenuhnya. Keluarga dan teman-teman dapat memainkan peran penting dalam mendukung penanggulangan psikologis pada dewasa muda yang menjadi subjek NSSI. Keluarga atau individu yang dekat dengan pelaku perlu mempertimbangkan makna dari perilaku menyakiti diri sehingga dapat membantu menemukan cara alternatif yang lebih sesuai dalam mengatasi tekanan emosional. Temuan ini menggarisbawahi pentingnya pemaknaan akan NSSI serta dinamikanya yang menunjukkan bahwa penemuan klinis yang hanya berfokus pada mencegah perilaku NSSI saja tidak cukup. Yang terpenting, perencanaan terapi dan dukungan sosial perlu dibuat dengan matang dan berkelanjutan mengingat adanya kecenderungan pelaku untuk mengulang menyakiti diri di masa depan.

\section{REFERENSI}

Adams, J., Rodham, K., \& Gavin, J. (2005). Investigating the 'self' in deliberate self-harm. Qualitative Health Research, 15, 1293-1309.

Arnett, J. J. (2000). Emerging adulthood: A theory of development from the late teens through the twenties. American Psychologist, 55(5), 469-480. https://doi.org/10.1037/0003066X.55.5.469

Arnett, J. J. (2016). College students as emerging adults: The developmental implications of the college context. Emerging Adulthood, 4(3), 219-222. https://doi.org/10.1177/2167696815587422

Biromo, A. R. (2015). Uji validitas dan reliabilitas Self-harm Behavior Questionnaire versi bahasa Indonesia [Tesis, Universitas Indonesia]. http://lib.ui.ac.id/file?file=digital/20165/20417225-SP-Anastasia\%20Ratnawati\%20Biromo.pdf

Bresin, K., \& Schoenleber, M. (2015). Gender differences in the prevalence of nonsuicidal selfinjury: A meta-analysis. Clinical Psychology Review, 38, 55-64. 
Brown, T. B., \& Kimball, T. (2013). Cutting to live: A phenomenology of self-harm. Journal of Marital and Family Therapy, 39, 195-208.

Chapman, A. L., Gratz, K. L., \& Brown, M. Z. (2006). Solving the puzzle of deliberate self-harm: The experiential avoidance model. Behaviour Research and Therapy, 44, 371-394.

Claes, L., Luyckx, K., \& Bijttebier, P. (2014). Non-suicidal self-injury in adolescents: Prevalence and associations with identity formation above and beyond depression. Personality and Individual Differences, 61-62, 101-104. https://doi.org/10.1016/j.paid.2013.12.019

Cooper, J., Hunter. C., Owen-Smith, A., Gunnell, D., Donovan, J., Hwaton, K., \& Kapur, N. (2011). 'Well it's like someone at the other end cares about you'. A qualitative study exploring the views of users and providers of care of contact-based interventions following self-harm. General Hospital Psychiatry, 33, 166-176.

Creswell, J. (2014). Research design. Sage.

Favazza, A. R. (2012). Nonsuicidal self-injury: How categorization guides treatment. Current Psychiatry, 11(3), 21-25.

Hamza, C. A., Willoughby, T. (2016). Nonsuicidal self-injury and suicidal risk among emerging adults. Journal of Adolescent Health, 59(4), 411-415. https://doi.org/10.1016/j.jadohealth.2016.05.019

Hawton, K., Saunders, K. E., \& O’Connor, R. C. (2012). Self-harm and suicide in adolescents. The Lancet, 379, 2373-2382.

Hume, M., \& Platt, S. (2007). Appropriate interventions for the prevention and management of selfharm: A qualitative exploration of service users' views. BMC Public Health, 7(1), 9.

Hunter, C., Chantler, K., Kapur, N., \& Cooper, J. (2013). Service user perspectives on psychosocial assessment following self-harm and its impact on further help-seeking: A qualitative study. Journal of Affective Disorders, 145, 315-323.

Kiekens, G., Hasking, P., Bruffaerts, R., Claes, L., Baetens, I., Boyes, M., Mortier, P., Demyttenaere, K., \& Whitlock, J. (2017). What predicts ongoing nonsuicidal self-injury? The Journal of Nervous and Mental Disease, 205(10), 762-770.

Klonsky, E. D. (2007) The functions of deliberate self-injury: A review of the evidence. Clinical Psychology Review, 27, 226-239.

Kranzler, A., Fehling, K. B., Anestis, M. D., \& Selby, E. A. (2016). Emotional dysregulation, internalizing symptoms, and self-injurious and suicidal behavior: Structural equation modeling analysis. Death Studies, 40(6), 358-366. 
Kurniawaty, R. (2012). Dinamika psikologis pelaku self-injury (Studi kasus pada wanita dewasa awal). Jurnal Penelitian dan Pengukuran Psikologi, 1(1), 13-22.

Liu, R. T., Cheek, S. M., \& Nestor, B. A. (2016). Non-suicidal self-injury and life stress: A systematic meta-analysis and theoretical elaboration. Clinical Psychology Review, 47, 1-14.

Mahtani, S., Melvin, G., \& Hasking, P. (2017). Shame proneness, shame coping, and functions of nonsuicidal self-injury (NSSI) among emerging adults. Emerging Adulthood, 6(3), 159-171.

Maidah, D. (2013). Self-injury pada mahasiswa (Studi kasus pada mahasiswa pelaku self-injury). Developmental and Clinical Psychology, 2(1), 6-13.

Mars, B., Heron, J., Crane, C., Hawton, K., Kidger, J., Lewis, G., Macleod, J., Tilling, K., \& Gunnell, D. (2014). Differences in risk factors for self-harm with and without suicidal intent: Findings from the ALSPAC cohort. Journal of Affective Disorders, 168, 407-414.

Martin, J., Bureau, J. F., Yurkowski, K., Fournier, T. R., Lafontaine, M. F., \& Cloutier, P. (2016). Family-based risk factors for non-suicidal self-injury: Considering influences of maltreatment, adverse family-life experiences, and parent-child relational risk. Journal of Adolescence, 49, 170-180.

National Institute for Clinical Excellence. (2011). Self-harm: Longer-term management (CG 133). NICE. Ditemu kembali dari https://www.nice.org.uk/guidance/cg133/evidence/fullguideline-184901581

Nock, M. (2008). Actions speak louder than words: An elaborated theoretical model of the social functions of self-injury and other harmful behaviors. Applied and Preventive Psychology, 12(4), 159-168.

O’Connor, R.C., Rasmussen, S., \& Hawton, K. (2009). Predicting deliberate self-harm in adolescents: A six month prospective study. Suicide and Life-Threatening Behavior, 39, 364-375.

Pickard, H. (2015). Self-harm as violence: When victim and perpetrator are one. Palgrave Macmillan.

Rodav, O., Levy, S., \& Hamdan, S. (2014). Clinical characteristics and functions of non-suicide self-injury in youth. European Psychiatry, 29(8), 503-508.

Rodham, K., Hawton, K., \& Evans, E. (2004). Reasons for deliberate self-harm: Comparison of self-poisoners and self-cutters in a community sample of adolescents. Journal of the American Academy of Child and Adolescent Psychiatry, 43, 80-87. 
Schwartz, S. J., Zamboanga, B. L., Luyckx, K., Meca, A., \& Ritchie, R. A. (2013). Identity in emerging adulthood: Reviewing the field and looking forward. Emerging Adulthood, 1, 96113. https://doi.org/10.1177/2167696813479781

Shaw, S. N. (2006). Certainty, revision, and ambivalence: A qualitative investigation into women's journeys to stop self-injuring. Women \& Therapy, 29, 153-175.

Sinclair, L., \& Leach, R. (2017). Exploring thoughts of suicide. BMJ, 30(356), j1128. https://doi.org/10.1136/bmj.j1128

Smith, J. A., Flowers, P., \& Larkin, M. (2009). Interpretative phenomenological analysis: Theory, method and research. Sage.

Smith, J. A. (2011). Evaluating the contribution of interpretative phenomenological analysis. Health Psychology Review, 5, 9-27.

Smith, J. A., \& Osborn, M. (2015). Interpretative phenomenological analysis as a useful methodology for research on the lived experience of pain. British Journal of Pain, 9(1), 4142.

Swahn, M. H., Ali, B., Bossarte, R. M., Van Dulmen, M., Crosby, A., Jones, A. C., \& Schinka, K. C. (2012). Self-harm and suicide attempts among high-risk, urban youth in the US: Shared and unique risk and protective factors. International Journal of Environmental Research and Public Health, 9(1), 178-191.

Taliaferro, L. A., \& Muehlenkamp, J. J. (2015). Risk factors associated with self-injurious behavior among a national sample of undergraduate college students. Journal of American College Health, 63(1), 40-48. https://doi.org/10.1080/07448481.2014.953166

Townsend, E. (2015). Self-harm in young people. Evidence-Based Mental Health, 17(4), 97-99. http://dx.doi.org/10.1136/eb-2014-101840

Turner, V. (2002). Secret scars: Uncovering and understanding the addiction of self-injury. Hazelden.

Victor, S. E., Muehlenkamp, J. J., Hayes, N. A., Lengel, G. J., Styer, D. M., \& Washburn, J. J. (2018). Characterizing gender differences in nonsuicidal self-injury: Evidence from a large clinical sample of adolescents and adults. Comprehensive psychiatry, 82, 53-60.

Victor, S. E., Hipwell, A. E., Stepp, S. D., \& Scott, L. N. (2019). Parent and peer relationships as longitudinal predictors of adolescent non-suicidal self-injury onset. Child and Adolescent Psychiatry and Mental Health, 13(1), 1-13. https://doi.org/10.1186/s13034-018-0261-0 
Vieira, M., Pires, M., \& Pires, O. (2016). Self-mutilation: Pain intensity, triggering and rewarding factors. Revista Dor, 17(4), 257-260. https://doi.org/10.5935/1806-0013.20160084

Wadman, R., Clarke, D., Sayal, K., Vostanis, P., Armstrong, M., \& Harroe, C., Majumder, P., \& Townsend, E. (2016). An interpretative phenomenological analysis of the experience of selfharm repetition and recovery in young adults. Journal of Health Psychology, 22(13), 16311641. https://doi.org/10.1177/1359105316631405

Whitlock, J., Minton, R., Babington, P., \& Ernhout, C. (2015). The relationship between nonsuicidal self-injury and suicide. The Information Brief Series, Cornell Research Program on Self-Injury and Recovery. Ditemu kembali dari http://www.selfinjury.bctr.cornell.edu/perch/resources/the-relationship-between-nssi-andsuicide-5.pdf

Willig, C. (2013). Introducing qualitative research in psychology. McGraw-Hill.

Wolff, J. C., Thompson, E., Thomas, S. A., Nesi, J., Bettis, A. H., Ransford, B., ... Liu, R. T. (2019). Emotion dysregulation and non-suicidal self-injury: A systematic review and metaanalysis. European Psychiatry, 59, 25-36. 